\title{
Heat potential evaluation of effluent and used thermal waters in Budapest, Hungary
}

\author{
Anita Erőss*, Ferenc Zsemle, Eszter Pulay \\ Department of Physical and Applied Geology, Eötvös Loránd University, Budapest, Hungary
}

Received: January 28, 2015; accepted: January 28, 2015

Europe's largest thermal water system can be found in the capital of Hungary. The springs and wells that supply the famous baths of Budapest discharge mainly from a regional Triassic carbonate rock aquifer system. The springs have mostly been substituted by wells; only a few natural springs are known today, most of which are drained unused into the Danube.

In this study, first the heat potential of these unutilized spring waters in the three natural discharge areas was assessed. Secondly, the heat potential of used thermal waters of three baths was calculated. At the springs discharge and temperature measurements were carried out. In the case of the baths, water management data were evaluated. At the Boltív Spring at the foot of Rózsadomb, the heat potential calculation shows that cooling the spring water to $5{ }^{\circ} \mathrm{C}$ would provide $6 \mathrm{MW}_{\text {th }}$ thermal capacity, providing a stable energy source for heat pumps. From the overflowing water of the springs of Rudas Bath at the foot of Gellért Hill, a total of $107 \mathrm{~kW}_{\text {th }}$ heat could be utilized when cooling it to $5{ }^{\circ} \mathrm{C}$, possibly by heat pump system. However, the heat potential of the Bründl Spring is not sufficient for geothermal utilization, mainly due to lack of end users in the vicinity of the spring. Together with the wastewater of the thermal baths, the effluent springs and wastewaters of pools carry a total of $25 \mathrm{MW}_{\text {th }}$ waste heat, which is a considerable amount compared to the needs of a public institution. The importance of this study is in the assessment of such potential heat sources (unused lukewarm and thermal springs, wastewater of spa pools) which are present either naturally or artificially, and do not require further thermal water production for heating purposes.

Keywords: heat potential, thermal waters, effluent spring waters, discharge measurements, geothermal utilization, spa

\footnotetext{
* Corresponding author: Pázmány Péter sétány 1/C, 1117 Budapest, Hungary;

E-mail: anita.eross@geology.elte.hu
} 


\section{Introduction}

The capital of Hungary, Budapest, developed into the city of spas owing to its particular hydrogeologic setting: Europe's largest natural thermal spring system can be found along the River Danube. This resource has been intensively utilized since Roman times, with the main focus on balneological use.

The springs and wells that supply the famous baths of Budapest discharge mainly from a regional Triassic carbonate rock aquifer system of the Transdanubian Range (TR; Fig. 1). The lithological continuity of the carbonate series in the TR facilitates the hydraulic continuity of the groundwater body, which is characterized mainly by gravity-driven groundwater flow (Alföldi 1979, 1982). One of the regional discharge areas of this carbonate rock aquifer system is located in Budapest, and it is represented by a step-faulted boundary between the subsided basin to the east (Pest) and the uplifted hilly range in the west (Buda). The course of the Danube follows this boundary and represents the base level of erosion (Fig. 2). The discharge zone of the system is situated essentially within the city districts, along the Danube, which is nowadays a fully urbanized environment. The natural springs have been mostly substituted by wells in the last eighty years, largely for sanitary reasons; only a few natural springs are known today, which flow, mostly unused, into the Danube.

Nowadays thermal water abstraction in the area is strictly regulated. Therefore further developments of energy use of thermal waters must consider these restrictions. The aim of the present study was to find available unutilized resources and assess their heat potential. First we considered the unused spring waters. To evaluate their possible utilization, the amount and temperature of effluent discharge must be measured. Secondly, the used thermal waters of the thermal baths, i.e. the wastewater from the pools, was taken into account, and its amount and temperature were

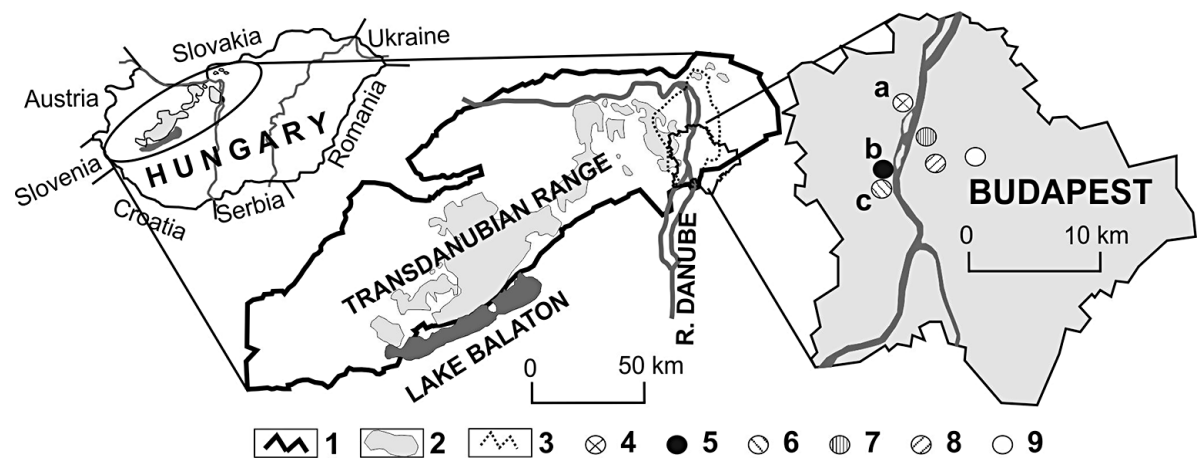

Fig. 1

Location of the study sites. 1: Subsurface boundary of Mesozoic carbonates, 2: Outcrops of Mesozoic carbonates in the Transdanubian Range, 3: Area of Buda Thermal Karst, 4: Bründl Spring, 5: Boltív Spring and the Lukács Bath, 6: Springs of the Rudas Bath, 7: Dagály Bath, 8: Széchenyi Bath, 9: Paskál Bath; Location of the natural discharge areas in Budapest. a: Northern discharge area, b: Central discharge area (Rózsadomb), c: Southern discharge area (Gellért Hill) 


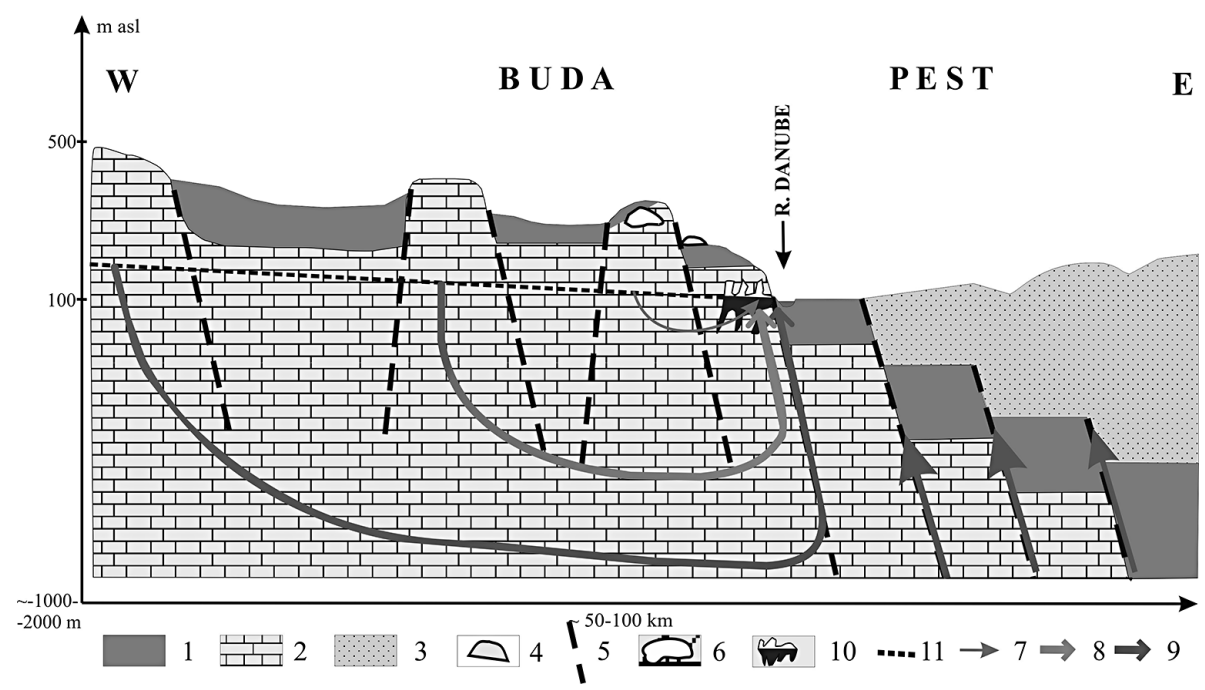

Fig. 2

Conceptual flow model of the Buda Thermal Karst system. 1: marls and clays; 2: carbonates; 3: Neogene sediments; 4: travertine; 5: fault; 6: inactive, dry cave; 7: local flow system; 8: intermediate flow system; 9: regional flow system; 10: active cave; 11: karst water table (modified after Eröss et al. 2008)

measured. This work summarizes the results of several students' theses, which were supervised by the authors (Zsuppán 2010; Csordás and Pataki 2012; Bodor and Lovrity 2014; Kurcz 2014).

\section{Site description}

Three distinct discharge zones can be distinguished in Budapest, based on the temperature of the discharging waters ( $a, b$ and $c$ in Fig. 1; Papp 1942; Alföldi 1982). In terms of natural conditions, in the North only lukewarm springs $\left(18-24^{\circ} \mathrm{C}\right)$ can be found. The spatially separated, tectonically-controlled discharge of lukewarm $\left(20-35^{\circ} \mathrm{C}\right)$ and hot $\left(40-65^{\circ} \mathrm{C}\right)$ springs was found to be characteristic for the central discharge area, at the foot of Rózsadomb, whereas in the Gellért Hill discharge zone, in the South, the springs can be characterized by temporally and spatially uniform temperature $\left(33.5-43.5^{\circ} \mathrm{C}\right)$ and chemical composition (1450-1700 mg/l TDS), which clearly differs from the hot waters at Rózsadomb (800-1350 mg/l TDS; Papp 1942; Eröss et al. 2008).

The Bründl Spring is the northernmost spring of the entire system (Schafarzik 1920; Fig. 1). Its water, which was used to supply a small bath, at a constant temperature of $18{ }^{\circ} \mathrm{C}$, nowadays flows unused into a ditch on the roadside (Kis-Csitári 2010). Concerning the geologic situation of the area (Fig. 3), the spring discharge is characterized by confined conditions and is possibly related to a structural element. 


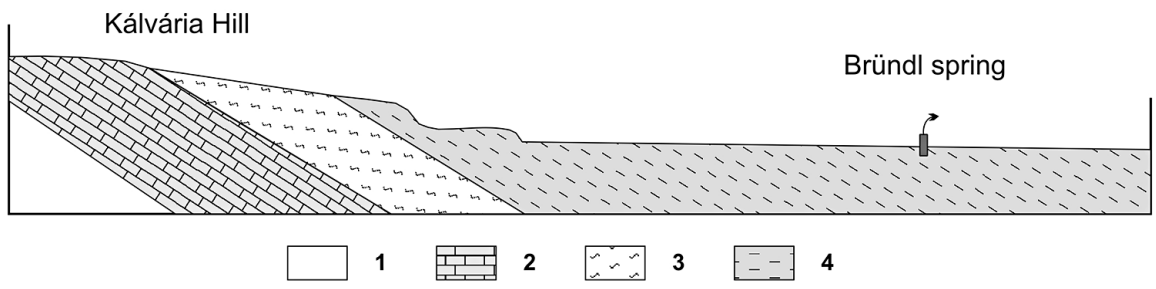

Fig. 3

Geological situation of the Bründl Spring. 1: Dachstein Limestone, 2: Szépvölgy Limestone, 3: Buda Marl, 4: Kiscell Clay (modified after Schafarzik 1920)

Based on the temperature of the spring a close recharge area and a local flow system can be assumed.

The Boltiv Spring at the foot of Rózsadomb is the only natural, free lukewarm spring outlet in the central discharge zone, which drains the Molnár János cave, one of the largest known active phreatic hydrothermal caves of the world. The spring water, discharging from an enlarged fracture of the Buda Marl, feeds the artificial Malom Lake, which is drained through a sluice and canal into the Danube, because of the urbanized environment, beneath the building of the Lukács Bath (Fig. 4).

The springs in the southern discharge area debouch from Triassic dolomite along the margin of Gellért Hill, its northeastern (springs of the Rácz Bath), eastern (springs of the Rudas Bath) and southeastern (spring of the Gellért Bath) side. Almost all natural spring outlets form a small cave, or have at least enlarged orifices, connected to faults and fractures. However, these spring caves were possibly isolated caves; most of them were opened during construction work at the beginning of the 1900s (Papp 1942). The overflowing water of the springs at the foot of Gellért Hill

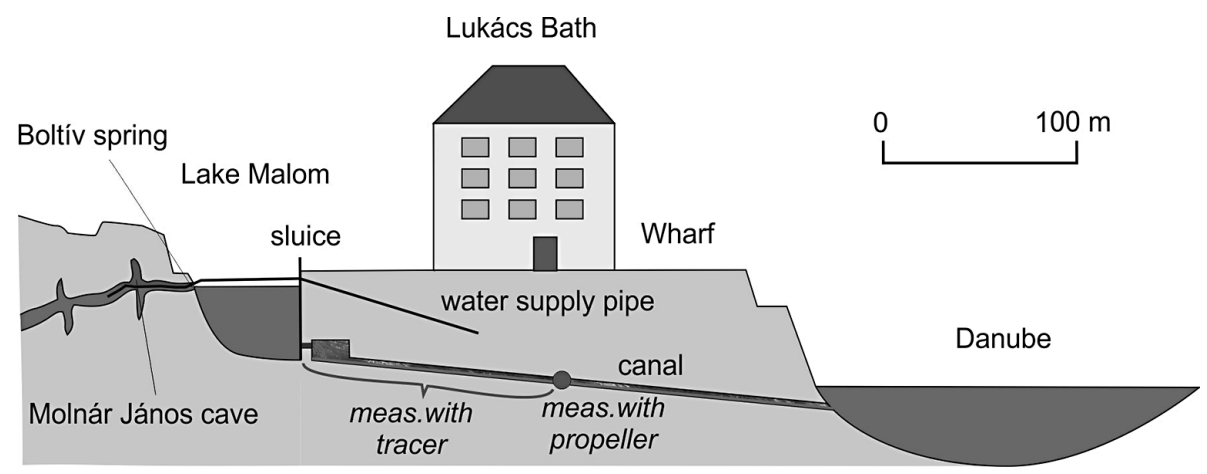

Fig. 4

Schematic cross-section at the foot of Rózsadomb showing the urbanized environment of the Boltív Spring 


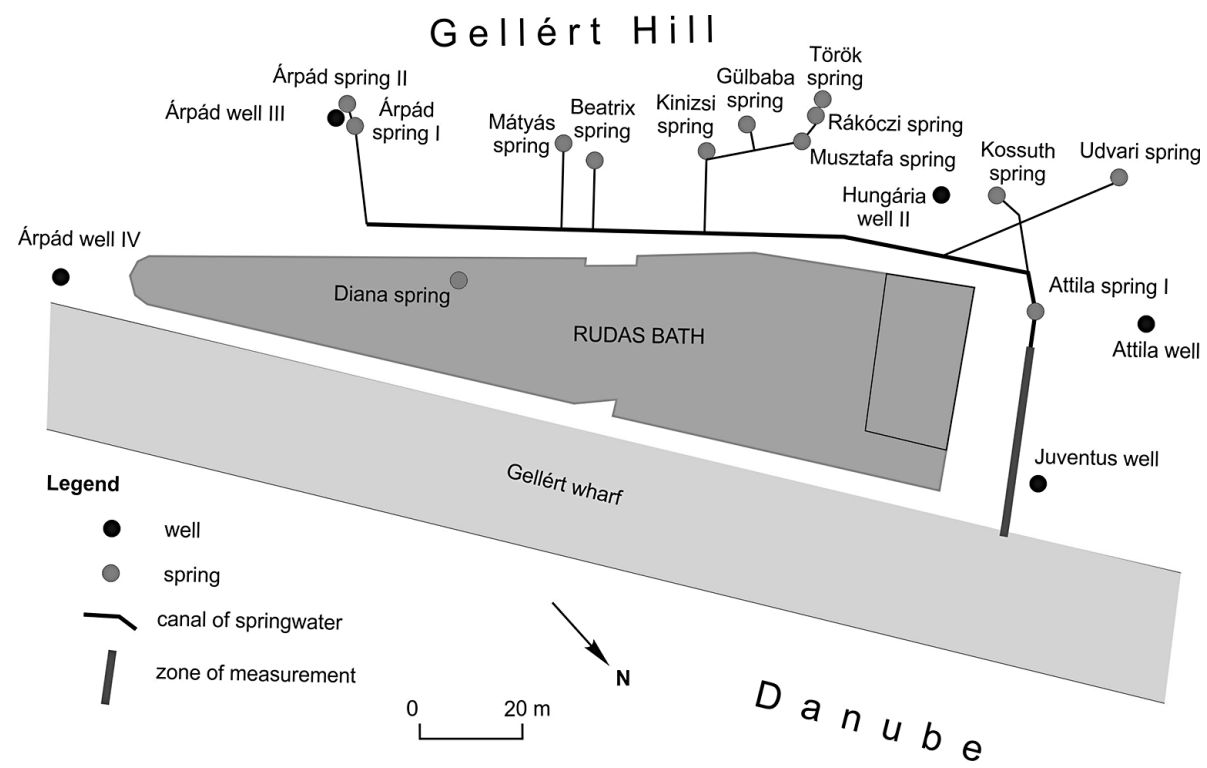

Fig. 5

Springs and wells in the front of Gellért Hill at Rudas Bath and the canal system collecting the effluent thermal water from the springs

close to the Rudas Bath is collected in a canal system and directed without utilization into the Danube (Fig. 5).

Among the spas using thermal water, four with the largest thermal water consumption (Paskál, Széchenyi, Dagály and Lukács) were investigated in terms of their water management (Fig. 1). Their water supply relies exclusively upon wells which are drilled in Eocene and Triassic carbonates and extract thermal water from the regional carbonate aquifer system.

\section{Methods}

\section{Discharge measurements}

In case of the Bründl Spring, the discharge measurement was carried out on 14 March 2013 with the jug and stopwatch method. We repeated the measurement three times and took the average. The temperature was measured with a WTW 340i multi-parameter field device.

At the Boltiv Spring, two methods were used to measure the discharge. Over the course of 8 months (October 2012-June 2013), measurements were made every four days in the Lukács Bath basement, in the canal with a propeller current meter. At the 
same time the water temperature was measured as well. With this method the average velocity of water flow across the canal's cross-section could be determined and by using the cross-section area the discharge was calculated.

The second technique used was based on the tracer attenuation method. On 23 November $20120.1 \mathrm{~g}$ uranin was dissolved in 1001 water and introduced at a constant rate $(0.045 \mathrm{l} / \mathrm{s})$ into the water flow at the sluice. The detection was accomplished with a GGUN-FL02 field fluorimeter (Schnegg and Doerflieger 1997) placed in the canal in the basement of the Lukács Bath, which allowed for a continuous measurement of the tracer concentration (Fig. 4). The success of the method relies on the perfect mixing at the cross-section of the water flow at the measuring point and on the continuous, constant injection rate. The entire measurement can be followed on a laptop connected to the fluorometer (using the fluorometer's own software). The discharge can be calculated with the following equation (Eq. 1):

$Q=q \times\left(c_{1} / c_{2}\right)$

where

$Q$ is the discharge of the water flow to be measured,

$q$ is the injection rate,

$c_{1}$ the prepared concentration of the injected tracer and

$c_{2}$ is the measured concentration of the tracer at the measuring point.

In the case of the springs of the Rudas Bath in the southern discharge area at the foot of Gellért Hill, the discharge and temperature measurement took place on 13 November 2009 in the final compartment of the canal system, collecting the overflowing water of the springs (Fig. 5). The discharge measurement was carried out by measuring the flow velocity and canal cross-section area. The conditions were not ideal for the velocity measurement as the canal configuration does not allow for the proper placement of a propeller current meter; also, the tracer for velocity measurement could only be applied to a short canal section. Detection of the tracer (Fuxin) was possible in a pit at the Danube bank, $40 \mathrm{~m}$ from the injection point.

\section{Water management data}

In the case of the investigated four Baths (Paskál, Széchenyi, Dagály and Lukács) that were chosen as examples for these heat utilization calculations because of their high water consumption, water management data from 2009 was made available by Budapest Spas cPlc. The company keeps records of the yield of the wells and the amount of wastewater. Wastewater includes all water from thermal and cold water wells and also, representing a few percent, public utility. During the field investigation temperature measurements were made of the wastewater from the pools, to complement the received data. 


\section{Heat potential calculation}

When considering the potential thermal outputs, this study did not take into consideration the technical challenges of the implementation of heat-utilizing systems. It only aims to show the scale of the amount of unutilized heat flowing away from the infrastructures.

Heat potential estimations were based on the heat egress of the water when cooled to $5{ }^{\circ} \mathrm{C}$. The temperature minimum was set to $5{ }^{\circ} \mathrm{C}$ for environmental reasons: to avoid freezing with certainly and to conserve the existing flora and fauna in the water. A simple method was applied, using the following formula:

$P_{t h}=c \times \Delta T \times m / t$

where

$P_{t h}:$ thermal power $[W]$,

c: $\quad$ specific heat of the water $(=4186[\mathrm{~J} /(\mathrm{kgK})])$,

$\Delta T$ : temperature change in the water $\left[{ }^{\circ} \mathrm{C}\right]$,

$m$ : mass of the cooled water [kg],

t: $\quad$ time $[\mathrm{s}]$.

Flow rate $[\mathrm{m} / \mathrm{t}]$ and temperature measurements carried out at the given measurement points were used to support the calculations. The resulting $\mathrm{P}_{\text {th }}$ value will represent the available thermal power from the flowing water that can be used by heat pumps or heat exchangers for direct heat utilization.

\section{Results}

At the Bründl Spring calculations were based on a single measurement. The discharge was $0.53 \mathrm{l} / \mathrm{s}$ and its temperature was $18.5{ }^{\circ} \mathrm{C}$. This yield is supposed to be of fluctuating nature, because the spring is an outlet of a local flow system (Fig. 3). However, based on similar archive data (Kis-Csitári 2010), our measurement can be considered as representative.

The heat potential calculation for the Bründl Spring resulted in a total of $30 \mathrm{~kW}_{\text {th }}$ when cooled to $5{ }^{\circ} \mathrm{C}$ (Table 1). The heat potential is not sufficient for commercial use, especially since there are no potential end users in the vicinity that could use the water/heat without the need of transportation. All these circumstances make this site unsuitable for geothermal utilization.

At the Boltiv Spring measurements over an 8-month time period were used for the calculation. The discharge of the Boltiv Spring calculated from the average velocity values across the canal varied between 75.8 and $129.71 / \mathrm{s}$, and during the 8 months averaged $95.9 \mathrm{l} / \mathrm{s}$. The tracer attenuation method, based on a single measurement, resulted in $71.8 \mathrm{l} / \mathrm{s}$ discharge. Studies showed that the fluctuation of the 
discharge is connected to the water level fluctuation of the Danube, as it represents the base level of erosion, but the precipitation events have no influence on it (Bodor et al. 2014). The temperature of the Boltív Spring water in the canal was stable, with a slight variation between $20-21.8^{\circ} \mathrm{C}$. It seems that the open water surface of the Malom Lake and the air temperature change do not exert any influence on the temperature of the spring.

Table 1

Heat potential of the spring waters and used thermal water from the investigated thermal spas

\begin{tabular}{llll}
\hline Source & $\begin{array}{l}\text { Water flow rate } \\
\mathrm{q}(\mathrm{l} / \mathrm{s})\end{array}$ & $\begin{array}{l}\text { Water temperature } \\
\mathrm{T}\left({ }^{\circ} \mathrm{C}\right)\end{array}$ & $\begin{array}{l}\text { Heat potential } \\
\text { when cooled to } 5^{\circ} \mathrm{C} \\
\mathrm{P}_{\text {th }}\left(\mathrm{MW}_{\text {th }}\right)\end{array}$ \\
\hline Bründl Spring & 0.53 & 18.5 & 0.03 \\
\hline Boltív Spring & 95.9 & 21 & 6.42 \\
\hline Rudas Spa springs & 0.9 & 33.5 & 0.11 \\
\hline Széchenyi Spa & 72 & 35 & 9.04 \\
\hline Dagály Spa & 59 & 36 & 7.66 \\
\hline Lukács Spa & 16 & 37 & 2.14 \\
\hline
\end{tabular}

The heat potential calculation for the Boltív Spring shows that cooling the water to $5{ }^{\circ} \mathrm{C}$ would provide $6.42 \mathrm{MW}_{\text {th }}$ thermal capacity (Table 1). Considering that the spring is located in a densely populated area, in the center of Budapest, this effluent water is a potential candidate for geothermal utilization.

At the foot of Gellerrt Hill the measured overflowing discharge of the springs of the Rudas Bath is $0.9 \mathrm{l} / \mathrm{s}$, based on a single measurement during low water conditions. The water temperature in the canal is $33.5^{\circ} \mathrm{C}$. By cooling this water to $5{ }^{\circ} \mathrm{C}$, a total of $107 \mathrm{~kW}_{\text {th }}$ heat could be utilized, possibly by heat pump system (Table 1). Earlier discharge measurements carried out by Alföldi et al. (1968) and Csepregi (1997) resulted in 3.5 and $8.3 \mathrm{l} / \mathrm{s}$ respectively. Spring discharge is influenced by the karst water level, and due to the vicinity of the Danube this is mainly controlled by the Danube level (e.g. Páll-Somogyi 2010); therefore the proper assessment of thermal water yield from these sources can only be carried out by systematic long-term monitoring. The potential user of this resource could be only the Rudas Bath.

At the investigated thermal spas the received flow rate data and the temperature measurements revealed that thermal utilizations possibilities are diverse. Although the Paskál spa uses thermal water, it does not operate in the winter; therefore, in this season where heating requirements increase, there is no constant wastewater flow available that this study could take into consideration. The other three spas drain away used water at $35-37^{\circ} \mathrm{C}$. Heat potential calculation from these spas is included in Table 1. 


\section{Conclusions}

In this study such potential heat sources (unused lukewarm and thermal springs, wastewater of spa pools) were assessed, which are present either naturally or artificially and do not require further thermal water production for heating purposes.

By analyzing the resulting data and our own on-site measurements it can be concluded that the stable temperature and the huge discharge rate of the Boltív Spring provide a stable energy source for heat pumps. The unused springs of the other two discharge areas were evaluated based on a single measurement each, although their heat potential should really be assessed based on a long-term monitoring program.

However, the usable but unused and wastewater of the investigated areas carry a total of $25 \mathrm{MW}_{\text {th }}$ (around 800,000 GJ/year) waste heat (Table 1), which is a considerable amount compared to the needs (300-3,000 GJ/year) of a public institution (schools, kindergartens, etc.). Since most of these resources are situated within the city, possible users can easily be found.

\section{Acknowledgements}

The Hungarian Scientific Research Fund (OTKA) has provided financial support to the project under the grant agreement no. NK 101356. The Budapest Spas cPlc. provided data and facilitated the measurements. Advice given by Imre Müller has been a great help in discharge measurements. The following MSc students of the Eötvös L. University are acknowledged for the measurements: Petra Bodor, Julianna Csordás, Teréz Kis-Csitári, Regina Kurcz, Vencel Lovrity, Lili Pataki, and Katalin Zsuppán. The valuable comments of reviewers are greatly appreciated.

\section{References}

Alföldi, L. 1979: Budapesti hévizek (Thermal waters of Budapest). - VITUKI Közlemények, 20, pp. 1-102. (in Hungarian)

Alföldi, L. 1982: A layered thermal-water twin flow system. - Journal of Hydrology, 56, pp. 99-105.

Alföldi, L., L. Bélteky, T. Böcker, J. Horváth, K. Korim, P. Liebe, R. Rémi 1968: Budapest Hévizei (Thermal waters of Budapest). - VITUKI, Budapest, 365 p. (in Hungarian)

Bodor, P., V. Lovrity 2014: A Boltív-forrás vízhozamának és fizikai, kémiai paramétereinek változása a csapadékesemények és a Duna vízállás függvényében. Értékelés archív adatok és recens mérések alapján (Temporal variation of the discharge and physico-chemical parameters of Boltív Spring depending on the precipitation and the waterlevel of the Danube. Evaluation based on archive data and recent measurements). - TDK thesis, ELTE TTK, 80 p. (in Hungarian)

Bodor, P., V. Lovrity, A. Erőss 2014: Evaluation of temporal variation of the discharge and physicochemical parameters of Boltív Spring (Budapest, Hungary). - Acta Mineralogica-Petrographica, Abstract Series, 8, $10 \mathrm{p}$.

Csepregi, A. 1997: A budapesti termálkarszt helyzetének értékelése. (Evaluation of the Buda Thermal Karst). - Manuscript 714/1/4032-1, VITUKI. (in Hungarian) 
Csordás, J., L. Pataki 2012: Elfolyó kilowattok! (Effluent kilowatts!). - TDK thesis, ELTE TTK, 59 p. (in Hungarian)

Erőss, A., J. Mádl-Szőnyi, A. Csoma 2008: Characteristics of discharge at Rose and Gellért Hills, Budapest, Hungary. - Central European Geology, 51/3, pp. 267-281.

Kis-Csitári, T. 2010: Az észak-budai langyos források állapotértékelése a használat kezdetétől napjainkig (Status assessment of the lukewarm springs in North Buda from the beginning of utilization until nowadays). - MSc Dissertation, ELTE TTK, 77 p. (in Hungarian)

Kurcz, R. 2014: Radionuklidok a Budai-hegység északi részének felszín alatti vizeiben (Radionuclides in the groundwaters in the Northern Buda Hills). - MSc Dissertation, ELTE TTK, 64 p. (in Hungarian)

Páll-Somogyi, K. 2010: A Duna hatásának vizsgálata a Gellért-hegy környezetének felszín alatti vizeire (Evaluation of the effect of the Danube on the groundwaters around the Gellért Hill). - Hidrológiai Tájékoztató, pp. 23-24. (in Hungarian)

Papp, F. 1942: Budapest meleg gyógyforrásai (Thermal springs of Budapest). - Budapesti Központi Gyógy- és Üdülőhelyi Bizottság Rheuma és Fürdőkutató Intézet, Budapest, 252 p. (in Hungarian)

Schafarzik, F. 1920: A budapesti termális vízhálózatnak egy eddigelé geologiailag nem méltatott forrásáról (About a geologically unappreciated spring among the thermalwaters in Budapest). Földtani Közlöny, 50, pp. 83-85. (in Hungarian)

Schnegg, P.A., N. Doerfliger 1997: An inexpensive flow-through field fluorometer. - In: Jeannin, P.Y. (Ed.): 6th Conference on Limestone Hydrology and Fissured Media. Proc. 12th Intern. Symp., pp. 47-50.

Zsuppán, K. 2010: A budapesti termálfürdők kifolyó vizeinek hőpotenciálja (Heat potential of the effluent waters of the thermal baths in Budapest). - MSc Dissertation, ELTE TTK, 70 p. (in Hungarian) 